\title{
Monetary policy transmission mechanism: A survey
}

\author{
Zuyi Wang1, a \\ ${ }^{1}$ Robert B. Willumstad School of Business, Adelphi University, New York 11530, USA; \\ azuyiwang @mail.Adelphi.edu
}

Keywords: Monetary economics, transmission mechanism, survey.

\begin{abstract}
The transmission problem of monetary policy plays an important role in the theory of monetary policy. Its conduction effect determines the performance of macroeconomic regulation and control, which influences the current and future policy decisions of the monetary authorities. The effective transmission of monetary policy is of great significance to promote economic development and stabilize economic fluctuation. This paper gives an overview of the monetary transmission mechanism, including its basic concept, development history and the channels of monetary transmission.
\end{abstract}

\section{Introduction}

The global financial crisis that has occurred in recent years has posed great challenges to world economic development. Apart from the problems in the product design of credit market, credit rating and mixed business models in financial market, the improper implementation of monetary policy of the Western countries, especially the United States, is the trigger of the crisis. The outbreak of the phased financial crisis has put forward a profound thinking and long-term in-depth study of the important issues for the world's central banks and the economic circles: through what kind of transmission mechanism can monetary policy truly achieve the maintenance of financial market stability and promote the steady development of the real economy? Monetary policy is an important component of a country's macroeconomic control, and the transmission mechanism of monetary policy has always been one of the core issues in the study of monetary policy theory. The monetary policy transmission mechanism describes the process by which real variables such as aggregate output and employment are affected by policy-induced changes in the nominal money stock or the short-term nominal interest rate [1].

As the main place of monetary policy transmission, the money market plays a key role, which is specifically manifested that it is not only a crucial carrier of monetary policy transmission with the conditions for the indirect transmission of monetary policy, but also the degree of currency market development is closely linked with the effectiveness of monetary policy transmission. The problem of the transmission effect of monetary policy plays an important role in the theory of monetary policy. Its transmission effectively determines the performance of macroeconomic regulation and control, which affects the current and future policy decisions of the monetary authorities. This paper systematically analyzes and reviews the theoretical development of the monetary policy transmission mechanism, and summarizes the four major channels of monetary policy transmission.

\section{The development history of monetary transmission mechanism}

Since the monetary policy transmission mechanism is the most important content regarding the impacts of monetary policy on the general economic conditions, over the years, economists have conducted long-term study in this area. The studies regarding the monetary policy transmission mechanism can be traced back to 1950's and 1960's, Roosa (1951) and Ando and Modigliani (1963) proposed the early theories of credit transmission mechanism and wealth transmission mechanism respectively [2, 3]. Later, Friedman (1970) further put forward the issue of monetary policy transmission mechanism more clearly, and stressed the importance position of monetary theory in the framework of monetary policy analysis [4]. The theory of money quantity has laid a solid foundation for the theoretical development of monetary policy transmission mechanism. 
The traditional theory of monetary policy transmission system research was originated from the interest rate channel, and its results are mainly reflected in the IS-LM macro model analysis of mainstream economics. In 1980s, Bernanke and Blinder (1988) extended the traditional IS-LM model by adding credit (ie, bank loan) elements to the traditional IS-LM model [5]. After this improvement, it can be theoretically explained that if the central bank adjusts monetary policy, such as raising or lowering the commercial bank deposit reserve, then the funds lent by commercial banks must be affected, so that enterprises and the self-employed investment business rely on bank loans are affected, which is finally transferred to the overall economic output, thus forming the socalled monetary policy "narrow credit" transmission channels. On the basis of the study of narrow credit channels, Bernanke and Gertler (1989) formally proposed the theoretical model of generalized credit channel [6]. In 1995, the Journal of Economic Perspectives published a special issue on the theoretical research of monetary policy transmission mechanism, and pushed the research of monetary policy transmission channel into a climax. Among them, Meltzer (1995) and Bernanke and Gertler (1995) respectively described the transmission mechanism of money channel and credit channel [7, 8]. In recent years, Lettau and Ludvigson (2003), Case and Quigley (2008) have further enriched the role of wealth effect in the monetary policy transmission mechanism by their research $[9,10]$.

\section{The channels of monetary transmission}

In reality, the choice of transmission channel is essential to the effect of monetary policy implementation. Therefore, the research on the transmission mechanism of monetary policy mainly focuses on the channels of monetary policy transmission. Monetary policy transmission mechanism is a multi-channel process, including interest rate channel, credit channel, asset price channel and exchange rate channel.

\section{Interest rate transmission mechanism}

Interest rate transmission mechanism is the most effective transmission mechanism of monetary policy transmission mechanism. In the 1930s, Keynes proposed liquidity preference theory, with the ultimate goal of stimulating the aggregate demand and improving production, established the interest rate transmission mechanism theory. In the interest rate transmission mechanism, the total conduction path is: money supply (M) promotes the change of interest rate ( $\mathrm{r}$ ), thus affecting the investment (I) and consumption (C), stimulates the aggregate demand (AD), and finally leads to the changes in output $(\mathrm{Y})$.

Transmission path of the interest rate can be divided into the following two specific ways:

In the first way, interest rate causes changes in aggregate demand by posing impact on investment, which can be expressed as $\mathrm{M} \rightarrow \mathrm{r} \rightarrow \mathrm{I} \rightarrow \mathrm{AD} \rightarrow \mathrm{Y}$. The transmission mechanism is based on the IS-LM model, which has two necessary prerequisites: (1) investment is flexible with changes in interest rates, which generally depends only on long-term interest rates. (2) monetary policy can affect the actual market interest rate in a long term. The transmission mechanism process is that when the money supply is increased, the market interest rate will decrease, the investment borrowing costs will be reduced, thus the investment demand will rise, and the investment multiplier effect will stimulate the increase of the total demand and the corresponding output will increase. On the contrary, when the money supply is reduced, the market interest rate will rise, resulting in a decline in demand for investment, which in turn reduces output.

The interest rate transmission mechanism was mainly to analyze the decision-making role of investment expenditure, and then extended to the role of consumer spending. Therefore, the second path of transmission path is that rate causes changes in aggregate demand by influencing the consumption, which can be manifested as $\mathrm{M} \rightarrow \mathrm{r} \rightarrow \mathrm{C} \rightarrow \mathrm{AD} \rightarrow \mathrm{Y}$. When the increase in money supply, the market interest rate declines. On the one hand, the residents' willingness to save reduces, which will promote the growth of consumption; on the other hand, the decline in market interest rates leads to the decline in foreign borrowing costs, prompting consumers to consume ahead of time. The increase in consumer demand stimulates aggregate demand growth, leading to higher output. 
On the contrary, when the market interest rates rise, people's consumer demand will be reduced, leading to a decline in output eventually.

\section{Credit transmission mechanism}

In the 1950s, the credit transmission mechanism was accompanied by the theory of credit availability. It was a transmission mechanism which was parallel to the traditional interest rate transmission mechanism, which made up the lack of taking into account the credit supply factor of the lender in the transmission mechanism. The credit transmission mechanism is divided into two transmission mechanisms, namely, the bank credit transmission mechanism and the balance sheet transmission mechanism.

(1) Bank credit transmission mechanism, which is represented as $M \rightarrow L \rightarrow I \rightarrow A D \rightarrow Y$. Bank credit transmission mechanism is established under the condition of underdeveloped financial market with asymmetric information. At this time, the central bank poses impact on credit expansion capacity of financial institutions (represented by banks) through monetary policy, thus affecting the financing capacity of enterprises. In the process of credit transactions, it is difficult for the bank to fully grasp the information of the borrower before the loan (L) is borrowed and to carry out a full range of supervision after the loan. Therefore, banks do not rely solely on for-profit and borrow high interest rates as borrowers to less secure borrowers. The mechanism of transmission is: when the money supply increases, due to increased bank credit availability, leading to an increase in credit investment for banks. The corresponding increase in aggregate demand for society has contributed to an increase in output. On the contrary, when the money supply is reduced, it will reduce the credit investment and reduce the output.

(2) Balance sheet transmission mechanism. The balance sheet transmission mechanism is divided into the transmission mechanism of the enterprise and of the resident individual according to the object.

The first way: the corporate balance sheet transmission mechanism, that is $\mathrm{M} \rightarrow \mathrm{r} \rightarrow \mathrm{NFC} \rightarrow \mathrm{AS} \& \mathrm{MH} \rightarrow \mathrm{L} \rightarrow \mathrm{I} \rightarrow \mathrm{Y}$. In this transmission mechanism, it plays a role mainly by influencing the net cash flow (NCF) of the firm. When the money supply increases, the market interest rate declines, which results in reduction of interest and other expenses, as well as the cash outflow, so that the NCF increases. At the same time, the decline of market interest means the rise of stock price rise, the value of corporate assets increases, so that the balance sheet gets enhanced. At this time, the borrower's value of the collateral increases, the reverse selection of the loan and the moral hazard are improved, and the amount of money spent on the investment increases and eventually contributes to the increase in output. On the contrary, the net cash flow will decrease as the money supply decreases, leading to a decrease in output.

The second way: balance sheet transmission mechanism of residents, that is $\mathrm{M} \rightarrow$ stock price $\rightarrow$ financial asset value $\rightarrow$ financial crisis $\rightarrow$ durable consumer goods, housing expenditure $\rightarrow$ Y. In this conduction mechanism, the liquidity effect is introduced for the strong liquidity of the stock, and the value of financial assets and the price of the stock have the correlation of changing in the same direction. The effect of liquidity will affect the utility of durable consumer goods and housing expenditure, so when the money supply increases, the stock price increases, the value of financial assets will increase, the corresponding family financial crisis decreases, residents' durable consumer goods and housing expenditure will increase, so that the total output increases. On the contrary, it will make the output decrease.

\section{Asset price transmission mechanism}

The asset price transmission mechanism includes the following two transmission channels:

(1) Tobin Q theory, which explains how to use monetary policy to influence stock prices and thus affect investment spending for transmission, that is $M \rightarrow P s \rightarrow q \rightarrow I \rightarrow Y$. One view is that when the money supply increases, the bond interest rate drops, for investors, the stock is more attractive than the bond at this point, so the demand for bonds reduces and the stock demand increases, the stock price $\left(P_{s}\right)$ increases; Another view shows that when the money supply increases, the currency held by people is out of demand, so they will increase the expenditure to buy stocks, thus stock prices rise. According to the above two views, it is clear to see that money supply stimulates investment 
spending by affecting the stock price. Therefore, Tobin put forward a very classic Q theory, where he defined the value of $\mathrm{q}$ as the ratio of market value to capital replacement: when $\mathrm{q}$ is higher than 1 , it indicates that the new equipment capital is lower than the market value, so the firm can get more new products by decreasing the number of stocks so as to increase investment expenses; When $\mathrm{q}$ is less than 1 , because the market value is lower than the equipment capital, companies will not buy new products, thus investment spending is reduced. The conduction mechanism of the Tobin Q theory can be simply described as: when the money supply increases, the market interest rate decreases and the stock price rises, which leads to an increase in the value of Q, and stimulates the firm to increase investment and eventually increases the output; conversely, when the money supply decreases, output will increase.

(2) Modigliani's consumer life theory, which explains how monetary policy can be conducted by influencing stock prices and then influencing consumer spending, that is $M \rightarrow P s \rightarrow V \rightarrow C \rightarrow Y$. The above-mentioned conduction process has made up for the lack of transmission of Tobin's theory, and has completed the asset price transmission mechanism from the aspect of consumer effect. Consumer life theory indicates that consumer spending is determined by the consumer's wealth (V), where the consumer spending is mainly for non-durable goods, the theory also divides wealth into financial assets and physical assets, of which shares are financial assets. So when the money supply increases, the market interest rate drops, the stock price will rise, the value of financial assets will rise, so that the consumer wealth increases, which stimulates consumption, so that consumer spending increases, eventually leading to increased output; on the other hand, when the money supply is reduced, the wealth is reduced, the consumption expenditure is reduced and the output is reduced.

\section{Exchange rate transmission mechanism}

The exchange rate mechanism is carried out under the condition of free flow of capital and without foreign exchange control. In fact, the interest rate transmission mechanism is also included. However, economist Robert Mundell argued that the flexible exchange rate system itself is a transmission mechanism, its process of transmission is $\mathrm{M} \rightarrow \mathrm{r} \rightarrow \mathrm{e} \rightarrow \mathrm{NX} \rightarrow \mathrm{Y}$ [11]. That is, when the money supply increases, the domestic market interest rates will decline, the attractiveness of domestic currency deposits will be relatively lower than foreign currency deposits, people will buy foreign currency and sell local currency, leading to the decline of exchange rate (e), making the terms of trade improved. The increase in market interest rates will lead to a decline in the exchange rate, a decrease in net exports, resulting in a decrease in output.

\section{Conclusions}

Monetary policy transmission mechanism is one of the most important research directions in monetary policy analysis. Since 2007, the global financial tsunami triggered by the US subprime mortgage crisis has raised new problems in the theoretical study of the monetary policy transmission mechanism. This paper takes the development of monetary policy transmission mechanism as a starting point, and mainly focuses on combing the monetary policy transmission mechanism of the four major transmission channels.

From a practical point of view, the monetary policy transmission mechanism plays a crucial role in global monetary policy formulation, implementation and analysis. However, due to different political systems, economic models and economic development stages of different countries, their choice of monetary policy transmission channels may vary. At the same time, in the real economic development, the monetary policy of the transmission mechanism is essentially a multi-channel integrated transmission mechanism. The central bank's monetary policy adjustment can not be effective only through one channel, yet through a number of channels at the same time on the overall economy. Therefore, issues like how to use the monetary policy tool in time and effectively in the current complex global economic structure, how to enhance the effectiveness of the monetary policy transmission mechanism and to develop a scientific sovereign wealth fund portfolio strategy 
within the framework of monetary policy so as to realize macro- and micro-financial stability, are in need of in-depth research and study.

\section{Reference}

[1] P. N. Ireland, "Monetary transmission mechanism," in Monetary Economics, ed: Springer, 2010, pp. 216-223.

[2] R. V. Roosa, "Interest rates and the central bank," Money, trade, and economic growth: in honor of John Henry Williams, pp. 270-95, 1951.

[3] A. Ando and F. Modigliani, "The" life cycle" hypothesis of saving: Aggregate implications and tests," The American economic review, vol. 53, pp. 55-84, 1963.

[4] M. Friedman, "A theoretical framework for monetary analysis," journal of Political Economy, vol. 78, pp. 193-238, 1970.

[5] B. S. Bernanke and A. S. Blinder, "Credit, money, and aggregate demand," ed: National Bureau of Economic Research Cambridge, Mass., USA, 1988.

[6] B. Bernanke and M. Gertler, "Agency costs, net worth, and business fluctuations," The American Economic Review, pp. 14-31, 1989.

[7] B. S. Bernanke and M. Gertler, "Inside the black box: the credit channel of monetary policy transmission," National bureau of economic research1995.

[8] A. H. Meltzer, "Monetary, credit and (other) transmission processes: a monetarist perspective," The Journal of Economic Perspectives, vol. 9, pp. 49-72, 1995.

[9] M. Lettau and S. Ludvigson, "Understanding trend and cycle in asset values: Reevaluating the wealth effect on consumption," National Bureau of Economic Research2003.

[10]K. E. Case and J. M. Quigley, "How housing booms unwind: income effects, wealth effects, and feedbacks through financial markets," International Journal of Housing Policy, vol. 8, pp. 161$180,2008$.

[11]R. A. Mundell, "A theory of optimum currency areas," The American economic review, vol. 51, pp. 657-665, 1961. 